\title{
Digital and Information Literacies and the School Library
}

\author{
Yvonne L Barrett \\ yvonne.barrett@blisankara.org \\ ylbarrett59@gmail.com \\ International Baccalaureate Organisation (IB)
}

Keywords: Information and digital literacies, multimodal literacies, new literacies, school libraries

\begin{abstract}
This presentation is based on a case study for a Master of Education (Digital Innovation and Knowledge Networks) through Charles Sturt University, Australia. Its focus was retrospective, to consider upper elementary students' learning experiences within a school library program. It endeavoured to explore the pedagogical background, motivation and steps in scaffolding the development of students' digital and information literacies. Did these sessions provide students with the emergent skills and strategies to support independent research and collaborative inquiry? While this case study was conducted in 2016, it still has practical relevance for school librarians today.
\end{abstract}

\section{Introduction and Case Study Context}

You can't teach people everything they need to know. The best you can do is position them where they can find what they need to know when they need to know it. (Seymour Papert)

For school librarians, this is certainly part of a core responsibility, to provide students with digital literacy skills and strategies that will enable them to find and access information at point of need, in order to create knowledge (Farkas, 2011). While students are growing up in this digital age, research reveals they are not necessarily skilled in reading to locate, and use online information effectively (Leu, Zawilinski, Forzani, \& Timbrell, 2014b; Pickard, Shenton \& Johnson, 2014). This is significant when "students overestimate their ability to engage with information in a critical and literate manner" (Kirkwood in Beetham \& Oliver, 2010, p. 162). Yet, students are required to be ethical and critical thinkers, and engage as collaborators and creators in participatory digital environments (Coiro, 2003; Mackey \& Jacobson, 2011; Association of College \& Research Libraries (ACRL), 2015).

This exploratory case study sought to investigate Year 5 students' (ages 10-12) learning experiences within a school library program. It endeavoured to explore the pedagogical background, motivation, and steps in implementing digital and information literacies. Did these sessions provide students with the emergent skills and strategies to support independent research, and collaborative inquiry as they began their International Baccalaureate Primary Years Programme (IB PYP) Exhibition?

Inquiry is the leading pedagogical approach of the IB. Teaching is conceptually based, and the school within the case study, follows an inquiry methodology. The PYP Exhibition is the culminating inquiry process where groups of students collaboratively take responsibility for their own learning and use critical 
thinking skills to engage with authentic learning experiences as they "problem solve and construct their own meaning and solutions to various social, cultural and political issues" (Koh, Tan, \& Ng, 2012 in Rochester, 2014, p. 1006).

The study involved ten classes within an international school setting in Singapore (213 students: 107 boys and 106 girls) over an academic school year. Students came from multiple cultural backgrounds and nationalities, including students with English as an Additional Language (EAL).

The focus of the information literacy (IL) sessions was to move beyond traditional library skills to focus on the perspective and experience of the user, and 'how to use information'; that is, to identify, navigate and evaluate information especially in online and digital spaces (Spiranec \& Banek Zorica, 2010). Weekly 35-minute lessons were conducted in a classroom setting. This time constraint is familiar to librarians who often have a short period to teach thereby limiting what can be covered (Farkas, 2012; Rush, 2014; Smale, 2012; van Meegen \& Limpens, 2010). Classroom teachers were part of these sessions to enable the ongoing development of these skills and strategies within their own classroom practice. Students accessed 1:1 iPad as well as using other digital technologies.

\section{Theories, Concepts and Literature}

The internet and participatory web 2.0 digital technologies and environments have been a major disruptive force in education, and society (Buschman, 2009; Dede, 2009; Farkas, 2012; Mackey \& Jacobson, 2011). This has seen the adjustment of pedagogical approaches to reflect the changed educational environment (Farkas, 2012). Simultaneously, students engage in informal learning experiences outside of the classroom, and access information at point of need (Farkas, 2012).

In this digital age, students need to be information fluent, and consider when information is needed. They need to decide which tools to use, to engage in critical thinking and analysis to evaluate, synthesize, and create new information - as well as be ethical users of data and information (ACRL, 2015; Mackey \& Jacobson, 2011). Students need to understand that information is not static but a dynamic entity (Mackey \& Jacobson, 2011; Rochester, 2014) and online information is now "characterized by pluralism, controversy, autonomy, fluidity, replicability and accessibility” (Spiranec \& Banek Zorica, 2010, p. 142). It is even more difficult when students are required to access, and quickly filter huge amounts of information and data within this interactive environment (Coiro, 2003; Dede, 2009). Yet, these are essential literacy 'survival' skills (Literat, 2014; Pickard, Shenton \& Johnson, 2014). This is problematic if students accept 'information on trust', and lack discrimination when selecting information from the internet (Pickard, Shenton \& Johnson, 2014).

\section{New Literacies}

Literature acknowledges the development of notions of transliteracy and new literacies (Mackey \& Jacobson, 2011; Leu et al., 2014a) with information literacy reframed as a metaliteracy connected to digital, media, visual, cultural, and environmental literacies (Mackey \& Jacobson, 2011; O'Connell, 2012; Rochester, 2014). Furthermore, it is recognized that the nature of literacy has been altered by the internet thus requiring additional skills and strategies (Leu et al., 2014b). So much so that "literacy is not just new today; it is new every day" (Leu, Forzani, Rhoads, Maykel, Kennedy \& Timbrell, 2014a, p. 38).

For school librarians, it is worthwhile to consider further the concept of Leu et al's (2014b) New Literacies theory, which embrace such findings as the centrality of critical literacies, the need for new forms of strategic knowledge, social practices, and new literacies in order for students to fully access the 
internet. This has implications for IL sessions when online research and comprehension is pivotal to the "process of problem-based inquiry involving the skills, strategies, dispositions, and social practices that take place as [students] use the internet" (Leu et al., 2014b, p. 346).

Leu et al. (2014b, p. 346) considered five processing practices that occur during online research. Reading to:

1. identify important questions

2. locate information

3. evaluate information critically

4. synthesize information; and

5. reading and writing to communicate information

Students need to be given explicit instruction, and ongoing opportunities to apply these complex reading processes in digital and online environments (Brown, 2014). Indeed, Henry argued "that locating information is perhaps, the most important function of reading on the Internet [as] all other decisions and reading functions...emanate from the decisions that are made during the search process" (2006, p. 616).

These new literacies are evident in both the revised SCONUL Seven Pillars of Information Literacy model and the ACRL Framework for Information Literacy for Higher Education which were used as curriculum design tools, along with the school library's "21st Century Skills - An Information Fluency Document" created by the Head Librarian. Each of these documents move beyond linear skills to include a holistic approach addressing knowledge practices, and dispositions i.e. affective, attitudinal or valuing dimensions of learning (Goldstein, 2015; Kutner \& Armstrong 2012; ACRL, 2015). These skills are developed systematically, at point of need, over an extended period and at a variety of levels (ACRL, 2015; Mackey \& Jacobson, 2011).

\section{Process}

Throughout the IL sessions, differentiation included a variety of teaching strategies, use of digital and visual tools, and groupings so students had opportunities for teacher directed focus, exploratory learning, and joint construction (Rochester, 2014). There were certainly "very different competencies, technological literacies and expectations" of students within the classroom (Farkas, 2012, p. 88). With such differences, it is a fine balance between providing the structure and scaffolding to teach IL and digital literacies skills, and providing students with the time to inquire, explore questions, and "wrestle with information issues collaboratively" (Farkas, 2012, p. 91). This is where the PYP Exhibition provided a window of guided/independent inquiry for students.

As the PYP Exhibition commenced, an exercise to use search terms and practice the online search process was conducted as part of the Tuning in and Finding out stages to support the PYP Exhibition transdisciplinary theme of 'How We Express Ourselves' during library sessions.

Parental permission was sought to allow for the Year 5 cohort to be involved in the case study. The focus was to observe students as to how they conducted their research, and whether they used the skills and strategies taught throughout the year during library sessions. This included taking a 'snapshot of learning' which included concept mapping, search history tracking, and watching/listening to over 50 screen recordings by students (in pairs or 'threes') using QuickTime Player. The latter allowed students to engage in Talk Alouds (Moline, 2010). A survey which included 194 students' perceptions of IL strategies

International Association of School Librarianship

https://iasl-online.org 
was also completed. These methods provided insight into the learner's viewpoint, and their active search strategy process.

\section{Information literacy sessions}

Based on the above literacies' practices and curriculum frameworks, the following steps to develop threshold conceptual understandings were taught during IL sessions.

Searching as a strategic exploration (ACRL, 2015) requires novice students to search a limited set of resources, and to construct a premeditated search strategy, that is, using Leu et al.'s (2014b) criteria, to read to identify important questions, and locate information.

While students were not introduced to the intricacies of how different search engines work, they were taught the structure of a web address and 'blurb' in order to infer the most useful links among a set of search engine results (Leu et al., 2014b; Henry, 2006). Students also used their prior knowledge along with these strategies to select useful web sites based on their information needs.

Students were asked to reflect on the importance of context and choice since "information sources [may] vary greatly in content and format and have varying relevance and value, depending on the needs and nature of the search" (ACRL, 2015, p. 9; Farkas, 2012; Spiranec \& Banek Zorica, 2010). As part of their conceptual understanding of searching as a strategic exploration, students explored multiple resources (including databases such as Newsbank, Ebscohost Student Reference Centre, online encyclopaedias, and websites) in order to read to locate, and critically evaluate information (Leu et al., 2014b; Mackey \& Jacobson, 2011; Moline, 2010).

Wikipedia as a resource was used for initial topic understanding, to access creative common images, as well as helping to narrow their own search terms by referring to subheadings within an article.

Additionally, students may discover further resources, via the citation trail, to support their inquiry. Wikipedia also allowed for differentiation of learner needs. Students with English as an additional language (EAL) were able to access to their mother language, and also the Simple English Wikipedia site. Students further engaged in discussions about online collaborative authorship, and reliability to develop their critical evaluation skills.

Alternative search engines to locate information, and to engage with the search process was introduced (Henry, 2006). Visual search engines such as Instagrok and Tag Galaxy showed the significance of the relationship of keywords and tags. Advanced search techniques, using Google and Google Images, gave students the experience of narrowing search terms by using filtering and search tools. Other search engines such as Gogooligans and DuckDuckGo were considered for their advertising-free, safe search features, and privacy settings.

Finally, students focused on the Tuning in stage to consider the purpose of their information need, and to create concept maps using keywords to narrow their topic before the start of the search task (Henry, 2006). 


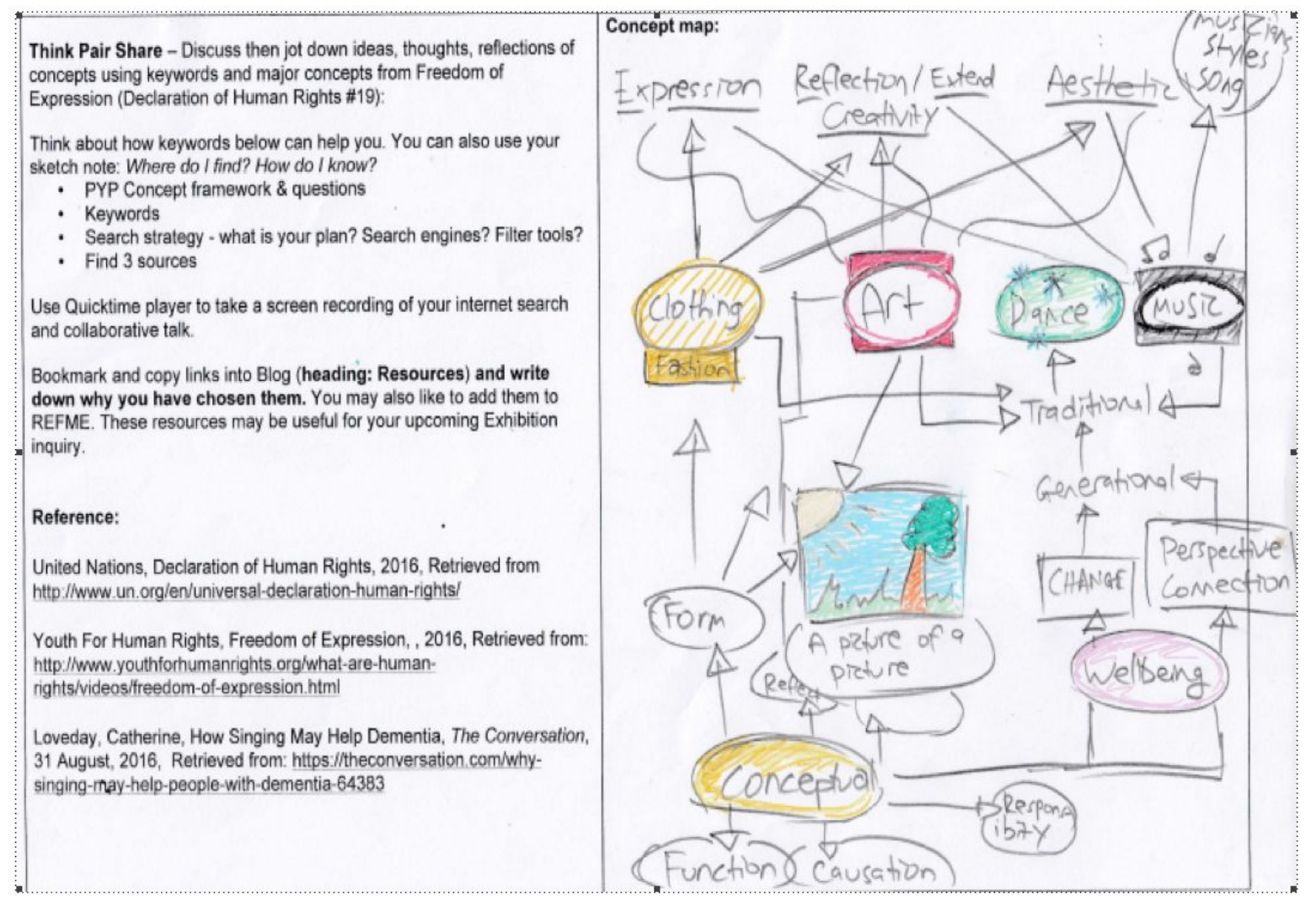

The conceptual understanding that authority is constructed and contextual (ACRL, 2015) introduce students to read in order to critically evaluate information (Leu et al., 2014b). Students considered how "information resources reflect their creators' expertise and credibility and are evaluated based on the information need and the context in which the information will be used" (ACRL, 2015, p. 4). Pickard, Shenton and Johnson noted how the skill of evaluation is one of the most difficult within the cognitive domain, and as a mainstream or gate-keeping skill "should be promoted by teachers in the classroom, as well as by librarians in the context of IL instruction" (2014, p. 4, p. 7). Indeed, for novice learners, design and presentation features rather than content can influence credibility judgements (Pickard, Shenton \& Johnson, 2014). In addition, social and digital technologies have made this even more difficult for students to determine the producer of information and author's expertise (Mackey \& Jacobson, 2011).

Librarians provide the scaffolding, so students can "judge the value, credibility and soundness of different sources of information or knowledge through comparison and critique, rather than to accept and present all information or knowledge as given" (Koh, Tan, \& Ng, 2012 in Rochester, 2014, p. 1009). Animated discussion was generated as students judged the reliability and authenticity of different hoax websites as an exercise in critically evaluating websites for information. Digital games such as Keynote Museum and Kahoot, other websites, and social media tools such as YouTube also provided appropriate learning experiences to explore and revise web evaluation.

As novice learners, students develop understandings of basic indicators such as authority and validity criteria (ACRL, 2015, SCONUL, 2011). This is especially important in the emergent stages until students can independently create their own knowledge, and transfer their learnings across disciplines (Moline, 2010; Rochester, 2014). The CARRDS Framework provided an evaluation scaffold, although students were reminded that this was only one framework among others available. Students made inferences based 
on credibility of author or organisation, the URL domain address clues, date/currency, references or citations, the purpose of the website, and reliability of information (which incorporated fact checking and utilising prior knowledge) as well as the relevance toward their information need.

As a final web evaluation task, students had the choice between websites to expose two websites with erroneous information, and to also consider the purpose of each website. Students were encouraged to think critically and "always question the information they read for reliability and accuracy, always read to infer bias or point of view, and always check the sources they encounter while reading" (Leu et.al., 2014b, p. 353; Henry, 2006; Mackey \& Jacobson, 2011).

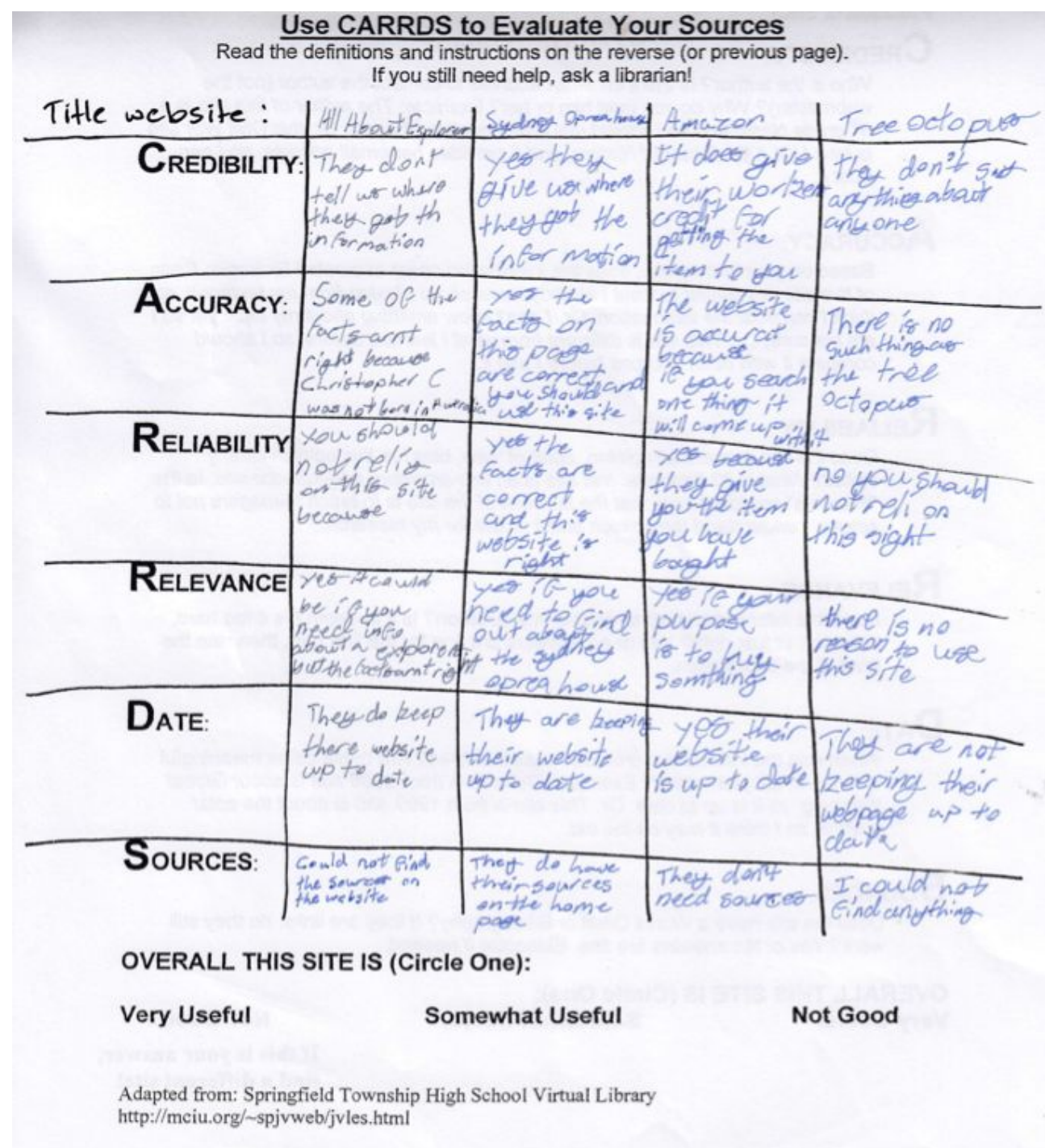

Information has value and scholarship as conversation (ACRL, 2015) were two other threshold conceptual understandings addressed. Students are very familiar with the concepts of reuse and remix in informal contexts as they create and participate in digital and online environments. What they do not understand are the legal and ethical nuances (Farkas, 2012). IL sessions introduced academic integrity and intellectual property, focusing on the concepts of plagiarism, copyright, creative commons, and referencing. A core element of presenting information to others is giving attribution, and communicating 
the sources used - indeed the key mantra was to 'Cite everything' and 'Cite as you go'. Students used the scaffold of the RefMe online citation tool to explore the proper attribution of multiple formats of information (Henry, 2006).

\section{Critical Analysis}

According to the online survey, the majority of students (91.2\%) considered the IL sessions helpful, agreeing between 3 and 5 on the Likert scale with 1 being (not a lot) to 5 (very helpful). However, the library program needs to also consider the extreme users, the remaining $8.7 \%$ who chose the Likert $1-2$ scales. As the survey was anonymous, it did not allow tracking to see who these students 'on the edges' were, as to implications for mother language, and reading abilities. Students agreed overwhelmingly that digital games are fun, interactive, and help them learn (See Figure 1). The survey has ramifications for how to differentiate teaching the IL and digital literacies for this group of students, and how digital games can be further incorporated within the school library programme.

\section{Figure 1 Sample student reflections of digital games}

Help me learn because they are fun so get me interested and make me want to get better and learn more so I do well in the game.

It makes me want to engage with the topic more.

It helps because if we get it wrong we discuss it and then explain why it is correct and it helps me to remember what we have learnt.

It helps because it will give questions you may not know the answer to and then it will tell you the answer and then it will explain why it was that answer.

Yes, because it's a fun game and because if you get something wrong your brain remembers the awnser.

Digital games help me because it transforms knowledge that was a bit boring to something that's really fun and helps me remember new information.

The fun games sink in your head; Because they help me understand more of the Internet.

Yes, because it's a fun way of learning important things that you'll need later \& now in life.

It was helpful because I learnt how to find trustworthy websites

It helps me by making my head think to the topic, so I will understand more.

Because it teaches you about how to search information and get information that is true.

I found it easier to engage during these games as an opposition to a teacher standing at the front of the room telling me something.

The data confirmed that Year 5 students, as novice learners of online reading, are beginning to apply their knowledge to different contexts. Students' concept maps as part of the goal setting process, showed students formulating search terms, yet also indicated the need for ongoing practice. This Tuning in stage is "critical to searching for information on the internet" (Henry, 2006, p. 618).

Screen recordings and informal in-class observation showed students engaged in discussion with one another and sharing prior knowledge. Working in small groups repositioned digital technologies as collaborative rather than individual tools. There was a balance of students using both natural language and selected keywords as they searched online. Several groups did not consider combining their search terms which affected both search results, and time management. While students indicated using a variety of resources, the internet is now the 'go to' resource for information across multimodal formats as shown in Figure 2.

International Association of School Librarianship

https://iasl-online.org 


\section{Figure 2: Sources of information used by upper elementary students}
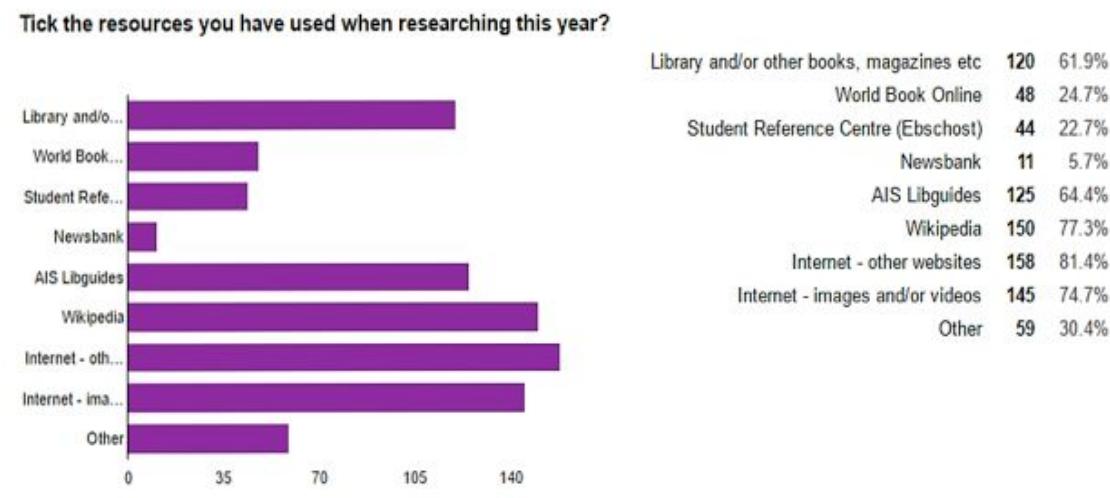

While students used different search engines, Google was the preferred search tool as shown in Figure 3. Student comments echoed each other, viewing Google as the 'most helpful' search engine based on their perceptions of familiarity and ease of use. Students viewed Google as providing fast, efficient, and relevant useful information in a variety of formats e.g. images, videos, news, calculator, and advanced search tools which allows the user to narrow their search. Interestingly, Mackey and Jacobson exclaimed that" the ease and ubiquity of resources such as the generic Google search feature, along with the certainty of results, however, lulls information seekers into a false sense of security that they have found what there is to be found" (2011, p. 71). Other students' preferences acknowledged the 'kid safe' and 'kid friendly' (easy to use and relevant information) aspects of search engines such as KidRex, DuckDuckGo, and Gogooligan. The other two resources that stood out for students to locate information was YouTube and Wikipedia.

\section{Figure 3: Students' preferred search engines}

Which search engine/s do you use when you look for online information? You may make multiple choices.

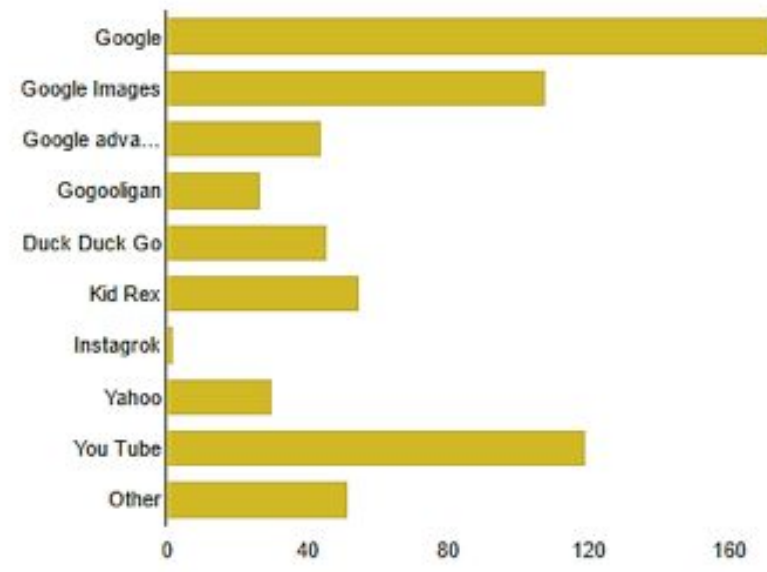

$\begin{array}{rrr}\text { Google } & 172 & 88.7 \% \\ \text { Google Images } & 108 & 55.7 \% \\ \text { Google advanced search } & 44 & 22.7 \% \\ \text { Gogooligan } & 27 & 13.9 \% \\ \text { Duck Duck Go } & 46 & 23.7 \% \\ \text { Kid Rex } & 55 & 28.4 \% \\ \text { Instagrok } & 2 & 1 \% \\ \text { Yahoo } & 30 & 15.5 \% \\ \text { You Tube } & 119 & 61.3 \% \\ \text { Other } & 52 & 26.8 \%\end{array}$

International Association of School Librarianship

https://iasl-online.org 
The snapshot of the recorded online 'search process' both confirmed student perceptions and introduced other concerns. One third of the student groups were seen to transfer learnings and understandings into practice when discussing issues ("Does this answer our question?", "Should we look in images?" "Is it trustworthy?" "That could be useful", "It has a real address and phone number", "Let's scroll down here and read") and using web evaluation criteria such as currency, authorship, reliability, relevance or the issue of online safety. These students also engaged in taking the time to scan and read for information.

Yet, the screen recordings also reinforced earlier research observations that students do not know how to approach reading in online environments (Henry, 2006; Timbrell, 2014). Despite the initial task outline to consider keywords, questions, and a search strategy before using the internet, many groups began using the internet without clarifying clear goals. The result was poor navigation skills, and a lack of focus evident in abandoning either search engines or websites without comprehending the content, random searching by jumping quickly between different search engines, and off topic conversation. Nor, did these groups take the time or show careful online reading of search results, address bar or websites, but instead engaged in non-strategic clicking only to find the information did not meet their information need or was too difficult for their reading comprehension. At this emergent stage, students are novice searchers who showed ad hoc search activity, and unable to engage with sufficient depth to fully explore the topic scope (Coiro, 2003; Debowski, 2001).

This anecdotal evidence is in direct contrast to students' perception on the importance of website evaluation criteria (See Table 1). Interestingly, there are still significant (while small) numbers of students (the extreme users, in red) who selected 1-2 on the Likert scale considering the criteria as 'not at all important' which has implications for both their own online search practice, online reading, and the school library program.

\section{Table 1: Frequency of responses provided for online survey website evaluation criteria}

\begin{tabular}{|l|c|c|c|c|c|}
\hline Response Statement & $\begin{array}{c}\text { 1. Not at all } \\
\text { important }\end{array}$ & $\mathbf{2 .}$ & $\mathbf{3 .}$ & $\mathbf{4 .}$ & $\begin{array}{c}\text { 5. Very } \\
\text { important }\end{array}$ \\
\hline $\begin{array}{l}\text { You look for } \\
\text { information about the } \\
\text { author or organisation }\end{array}$ & $2(1 \%)$ & $14(7.2 \%)$ & $29(14.9 \%)$ & $69(35 / 6 \%)$ & $80(41.2 \%)$ \\
\hline $\begin{array}{l}\text { The information is } \\
\text { detailed rather than } \\
\text { brief }\end{array}$ & $3(1.5 \%)$ & $7(3.6 \%)$ & $42(21.6 \%)$ & $81(41.8 \%)$ & $61(31.4 \%)$ \\
\hline $\begin{array}{l}\text { The web page/site is } \\
\text { new or has been } \\
\text { recently updated }\end{array}$ & $2(1 \%)$ & $8(4.1 \%)$ & $29(14.9 \%)$ & $73(37.6 \%)$ & $82(42.3 \%)$ \\
\hline $\begin{array}{l}\text { The web page refers to } \\
\text { the work of other } \\
\text { experts or has a } \\
\text { reference list }\end{array}$ & $3(1.5 \%)$ & $7(3.6 \%)$ & $51(26.3 \%)$ & $71(36.6 \%)$ & $62(32 \%)$ \\
\hline
\end{tabular}

International Association of School Librarianship https://iasl-online.org 


\begin{tabular}{|l|c|c|c|c|c|}
\hline $\begin{array}{l}\text { There are no spelling } \\
\text { or grammatical } \\
\text { mistakes }\end{array}$ & $6(3.1 \%)$ & $7(3 / 6 \%)$ & $26(13.4 \%)$ & $51(26.3 \%)$ & $104(53.6 \%)$ \\
\hline $\begin{array}{l}\text { It is clear why the } \\
\text { website has been } \\
\text { created }\end{array}$ & $0(0 \%)$ & $9(4.6 \%)$ & $33(17 \%)$ & $64(33 \%)$ & $88(45.4 \%)$ \\
\hline $\begin{array}{l}\text { You read the search } \\
\text { page blurb and look at } \\
\text { the URL address for } \\
\text { clues }\end{array}$ & $6(3.1 \%)$ & $13(6.7 \%)$ & $41(21.1 \%)$ & $78(40.2 \%)$ & $56(28.9 \%)$ \\
\hline $\begin{array}{l}\text { You use prior } \\
\text { knowledge when } \\
\text { using search engines } \\
\text { and choosing websites }\end{array}$ & $2(1 \%)$ & $4(2.1 \%)$ & $23(11.9 \%)$ & $78(40.2 \%)$ & $87(44.8 \%)$ \\
\hline $\begin{array}{l}\text { It is easy to check the } \\
\text { information is correct } \\
\text { by looking at other } \\
\text { websites }\end{array}$ & $0(0 \%)$ & $9(4.6 \%)$ & $23(11.9 \%)$ & $71(36.6 \%)$ & $91(46.9 \%)$ \\
\hline $\begin{array}{l}\text { You think about } \\
\text { keywords you will use } \\
\text { before searching } \\
\text { online }\end{array}$ & $2(1 \%)$ & $7(3.6 \%)$ & $30(15.5 \%)$ & $85(43.8 \%)$ & $70(36.1 \%)$ \\
\hline $\begin{array}{l}\text { You choose different } \\
\text { search engines } \\
\text { depending on how } \\
\text { they can help you find } \\
\text { information }\end{array}$ & $6(3.1 \%)$ & $10(5.2 \%)$ & $29(14.9 \%)$ & $66(34 \%)$ & $83(42.8 \%)$ \\
\hline
\end{tabular}

\section{Recommendations}

The demands of evaluating information would appear to be insufficiently valued in education (Pickard, Shenton \& Johnson, 2014). The case study reaffirmed Debrowski's (2001) findings of the need for further exploration of students' search strategies. It would certainly be interesting to track these students as they move through the secondary years, as to how their research, and online comprehension develop. While there are obvious limitations to the case study especially the time constraint of both the IL sessions it is still evident that the following skillsets and strategies need to be continually reinforced within the school library program, and the classroom:

1. Practicing searching and analysing search engine results, including strategic use of keywords and "determining the extent of information required for a particular search" (Mackey \& Jacobson, 2010, p. 68; Henry, 2006).

2. Providing time for students to inquire and explore multiple formats in order to activate prior knowledge to help with searching on the internet (Henry, 2006). 
3. Students evaluating and annotating websites as part of inquiry tasks - in addition to content creation - that, is, including why they have selected websites to use.

4. Opportunities for student reflection of tools and strategies used within a search process, and whether it was effective (Henry, 2006; Farkas, 2012).

5. Revising conceptual understandings of academic integrity and practicing bibliographic skills throughout the academic year within the classroom context.

\section{Conclusion}

The case study provided interesting insights into students' emergent digital and information literacies skills. Students were seen to begin to apply the information learned within the IL sessions to different contexts. Yet, the qualitative data from the snapshot of learning also reaffirmed the literature and the dichotomy that exists between student's beliefs and perceptions, and their actual skills in reading to effectively navigate, locate, evaluate, and use online information. While students acknowledged the significance of digital and information skills and strategies within the online survey, they are still very much novice learners 'finding their way online' without much thought given to their practice.

Given the impact of digital technologies and participatory environments today, information literacies are now even more significant (Mackey and Jacobson, 2011). Students in the case study are already familiar with the dynamics of change as they live in cultures outside of their own. As they progress through their schooling, however, students need to make similar connections, and develop the skills and strategies to successfully engage with the new literacies in complex digital and online environments.

\section{REFERENCES}

Association of College \& Research Libraries (ACRL). (2015). Framework for information literacy for higher education. Retrieved from http://www.ala.org/acrl/standards/ilframework

Beetham, H. \& Oliver, M. (2010). The changing practices of knowledge and learning. In Sharpe, R., Beetham, H., \& de Freitas, S (ed.), Rethinking Learning for a Digital Age, 155-169.

Brown, C.A. (2014). Pedagogy and the new literacies in higher education, In V. Wang (Ed.), Handbook of Research on Education and Technology in a Changing Society, 792-805. Hershey, PA: https://doi.org/10.4018/978-1-4666-6046-5.ch059

Buschman, J. (January 2009). Information Literacy, "New” Literacies, and Literacy. The Library Quarterly, Volume 79, Number 1 (January 2009), 95-118. https://doi.org/10.1086/593375

Coiro, J. (2003). Reading comprehension on the Internet: Expanding our understanding of reading comprehension to encompass new literacies. The Reading Teacher, 56(5), 458-464.

Debowski, S., (2001). Wrong way: go back! An exploration of novice search behaviours while conducting an information search. The Electronic Library, 19(6), 371-382. https://doi.org/10.1108/02640470110411991 
Dede, C. (2010). Comparing Frameworks for "21st Century Skills". 21 st Century Skills: Rethinking How Students Learn, Chapter 3. (Ed.) James A. Bellanca, Solution Tree Press, 21 Sep 2011. Retrieved from http://www.watertown.k12.ma.us/dept/ed_tech/research/pdf/ChrisDede.pdf

Farkas, M. (2012). Participatory technologies, pedagogy 2.0 and information literacy. Library Hi Tech, 30(1), 82-94. https://doi.org/10.1108/07378831211213229

Henry, L.A., (2006). SEARCHing for an answer: The critical role of new literacies while reading on the Internet. International Reading Association, 614-627. https://doi.org/10.1598/rt.59.7.1

Kutner, L. \& Armstrong, A. (2012). Rethinking information literacy in a globalized world.

Communications in Information Literacy, 6(1), 24-33.

https://doi.org/10.15760/comminfolit.2012.6.1.115

Leu, D.J., Forzani, E., Rhoads, C., Maykel, C., Kennedy, C., \& Timbrell, N. (2014a). The new literacies of online research and comprehension: Rethinking the reading achievement gap. Reading Research Quarterly, 50(1). 37-59. Newark, DE: International Literacy Association. doi: 10.1002/rrq.85. Retrieved from http://www.edweek.org/media/leu\%20online\%20reading\%20study.pdf

Leu, D.J., Zawilinski, L., Forzani, E. \& Timbrell, N. (2014b). Best practices in teaching the New Literacies of Online Research and Comprehension [in press]. 343-364. Retrieved from http://newliteracies.uconn.edu/wp-content/uploads/sites/448/2014/07/Leu-D.J.-Zawilinski-L.-For zani-E.-Timbrell-N.-in-press.pdf

Literat, I. (2014). Measuring new media literacies: Towards the development of a comprehensive assessment tool. Journal of Media Literacy Education, 6(1), 15-27. Retrieved from http://digitalcommons.uri.edu/cgi/viewcontent.cgi?article=1141\&context=jmle

Mackey, T.P. \& Jacobson, T.E. (2011). Reframing literacy as a metaliteracy. College \& Research Libraries, 72(1), 62-78. https://doi.org/10.5860/crl-76r1

Moline, T. (2010). Video games as digital learning resources: Implications for teacher-librarians and for researchers. School Libraries Worldwide. 16(2), 1-15.

O'Connell, J. (2012). Learning without frontiers: School libraries and meta-literacy in action. ACCESS. 26(1), 4-7. Retrieved from

http://www.asla.org.au/publications/access/access-commentaries/school-libraries-and-meta-literac y.aspx

Pfannenstiel, N. (2010). Digital literacies and academic integrity. International Journal for Educational Integrity, 6(2), 41-49.

Pickard, A.J., Shenton, A.K. \& Johnson, A. (2014). Young people and the evaluation of information on the World Wide Web: Principles, practice and beliefs. Journal of Librarianship and Information Science, 46(1), 3-20. https://doi.org/10.1177/0961000612467813 
Rochester, R. R. (2014). Multiliteracies pedagogy. In V. Wang (Ed.), Handbook of Research on Education and Technology in a Changing Society, 1005-1013. Hershey, PA: doi:10.4018/978-1-4666-6046-5.ch008

Rush, L. (2014). Learning through play, the old school way: Teaching information ethics to millennials, Journal of Library Innovation, 5(2), 1-14.

SCONUL (2011). The SCONUL seven pillars of information literacy core model for higher education. Retrieved from http://www.sconul.ac.uk/page/seven-pillars-of-information-literacy

Smale, M. A. (2012). Get in the game: Developing an information literacy classroom game. Journal of Library Innovation, 3(1), 126-147. https://doi.org/10.1353/lib.2013.0011

Spiranec, S. \& Banek Zorica, M. (2010). Information literacy 2.0: hype or discourse refinement? Journal of Documentation, 66(1), 140-153. http://do.doi.org/10.1108/00220411011016407

Timbrell, N. (9 May 2014). Using reciprocal reading strategies to boost online reading comprehension, IRA Institute: Intentional Teaching with Technology, Retrieved from: http://goo.gl/5MyFaF

Timbrell, N. (9 May 2014). Reciprocal reading strategies in offline and online reading environments. Retrieved from

https:/tilesig.wikispaces.com/file/view/Reciprocal+Teaching+Roles+Matrix+-+FINAL-2.pdf

Transue, B.M. (2013). Connectivism and information literacy: Moving from learning theory to pedagogical practice. Public Services Quarterly, 9, 185-195.

https://doi.org/10.1080/15228959.2013.815501

Van Meegen, A. \& Limpens, I. (2010). How serious do we need to be? Improving information literacy skills through gaming and interactive elements. Liber Quarterly, 20(2), 270-288. https://doi.org/10.18352/lq.7993

\section{Biographical Note}

Yvonne L. Barrett is an experienced teacher librarian and workshop leader for the International Baccalaureate Organisation (IB). After gaining a Bachelor of Arts and Teacher qualifications, Yvonne continued with a Post Graduate degree in Information Science/Teacher Librarianship at the University of Technology Sydney, Australia. She received a Master of Education, Knowledge Networks and Digital Innovation from Charles Sturt University, Australia. Yvonne has 25 years working in both Australian and international K-12 school library environments. She is an advocate of "communities of practice" and enjoys the collegiality, and open sharing of the international school librarian community. Yvonne has 
presented at conferences in both the Asia Pacific and European regions. Yvonne is currently teacher librarian at Bilkent Laboratory and International School, Ankara, Turkey. 